\title{
CHARACTERIZATION OF SURFACE AND SUB-SURFACE DEFECTS IN OPTICAL MATERIALS USING THE NEAR FIELD EVANESCENT WAVE
}

Ming Yan, Stanley Oberhelman, Li Wang, Wigbert Siekhaus, and Mark Kozlowski

\author{
Lawrence Livermore National Laboratory, L-250, \\ Livermore, CA 94551 , USA \\ phone: 925-423-1608 fax: 925-422-3361 \\ e-mail:yan1@llnl.gov
}

KEY WORDS: Near field optics, characterization of surface and sub-surface defects,

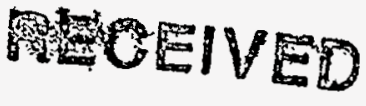
HOV 091998 evanescent wave, laser induced damage, fused silica, and optical coatings.

\section{INTRODUCTION}

Optical properties of sub-micron defects at and near the surface are of interest in many applications, e.g. in high power laser systems where initiation of laser induced damage is a critical issue. In-situ scanning atomic force microscopy (AFM) has been used previously to establish a direct correlation between a particular structural surface inhomogeneity (such as a nodular defect in coatings) and the initiation of local laser damage at that inhomogeneity ${ }^{1}$. Near field scanning optical microscopy (NSOM) make it now possible to provide information on both morphology and optical properties of localized defects at and near the surface $e^{2-3}$. As a consequence of these developments one can now test the correlation between local optical properties and laser surface damage.

\section{EXPERIMENTAL RESULTS AND CONCLUSIONS}

In this paper, we characterize surface and sub-surface defects in fused silica and optical coatings using the surface evanescent wave measured by NSOM implemented on a large-stage AFM. A laser irradiates the sample surface in a total internal reflection configuration. The evanescent wave from the surface is collected by an apertured fiber probe of the NSOM. The amplitude of the surface evanescent wave is proportional to the laser intensity at the surface and therefore sensitive to surface as well as sub-surface defects located in the near-field range $(\sim 100 \mathrm{~nm})$. This subsurface region is thought to contain the great majority of polishing-induced defects. The apertured near field fiber probe provides a spatial resolution of $\sim 100 \mathrm{~nm}$ and the large stage AFM makes it possible to locate defects in samples with diameters up to 6 ". We are thus able to map out surfaceas well as near-surface optical defects in a large optic, as shown in figure 1, as a first step in understanding laser damage mechanisms. These observed defects will be exposed in situ to high fluence laser light to correlate with the initiation of laser damage. We have also 
used NSOM to measure in situ the effect of chemical etching on optical properties of defects. Post-processing such as chemical etching performed after mechanical polishing is frequently used, and sometimes increases laser damage thresholds.

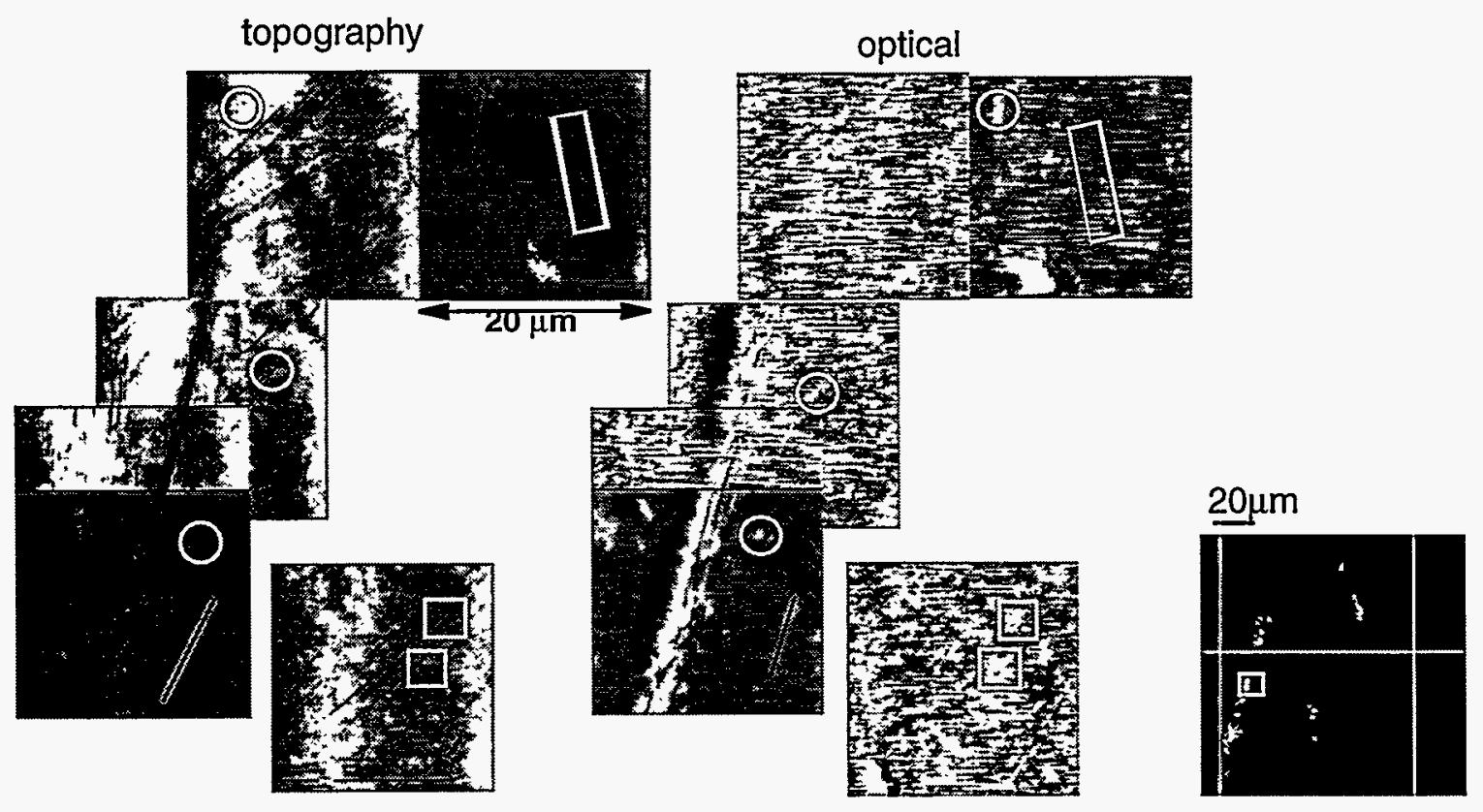

Figure 1. Topographic NSOM images (left) and optical evanescent wave NSOM images (middle) of a large area (each image is $20 \mu \mathrm{m}$ square) of a polished fused silica surface. The image at the right (shown for comparison) is a conventional total internal reflection image.

We have measured the amplitude variation of the near field evanescent wave around nodular defects and sub-surface inclusions in optical coatings and thus detected local laser field intensification. The observed intensity variation of the evanescent wave agrees with theoretical calculations of laser amplification around the inclusion. These findings support the theory that laser damage may be induced by local electrical field enhancement associated with micron and sub-micron defects.

\section{REFERENCES}

[1] R. J. Tench, R. Chow, and M. R. Kozlowski, "Characterization of defect geometries in multilayer optical coatings" J. Vac. Sci. and Tech. A 12/5, 2808 (1994)

[2] L. Wang, M. Yan, W. Siekhaus, and Stanley Oberhelman "Probing nanodefects in fused silica by near field scanning optical microscopy" J. Appl. Phys. Vol.84, N6, 1998. [3] M. Yan, L. Wang, W.J. Siekhaus, M.R. Kozlowski, J. Yang, U. Mohideen "Defects studies in fused silica using near field scanning optical microscopy"SPIE $\underline{3244}$, 268(1997)

\section{ACKNOWLEDGMENT}

This work was performed under the auspices of the US Department of Energy by Lawrence Livermore National Laboratory under contract No. W-7405-ENG-48. 


\section{DISCLAIMER}

This report was prepared as an account of work sponsored by an agency of the United States Government. Neither the United States Govesnment oor any agency thereof. nor any of their employees, makes any warranty, express or implied, or assumes any legal liability or responsibility for the zecuracy, compieteress, or usefulness of any information, apparatus, produer, or process disclosed. or represents that its use would not infringe privately owned rights. Refereace berein to any speciric commercial product, process, or serviee by trade name, traderazth, inanufac. turet, or otherwise does not aecessarily constitute or imply its eadorsement. recommendation, or favoring by the United States Goverameat or any ageacy thereof. The views and opinions of authors expressed herein do not aecessarily state or reflect those of the United States Government or any agency thereof. 


\section{DISCLAIMER}

Portions of this document may be illegible in electronic image products. Images are produced from the best available original document. 